症 例

術前に診断した右傍十二指腸ヘルニアの 1 例

寺元記念病院外科

大田浩平柳川憲一高畑哲也

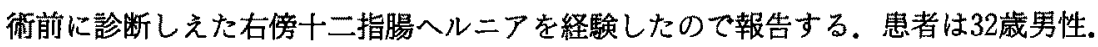
主訴は上腹部痛. 腹部所見では上腹部に圧痛を伴う膨隆を認めた。腹膜刺激症状は認め ず. 28歳時にも同様の症状を認めたが数日の入院加療で軽快している.腹部単純レント ゲン検查では右側結腸内のガス像が肝下面へ圧排されていた，腹部造影 CT 検查にて上 行結腸の内側，横行結腸の背側から尾側に径 $12 \mathrm{~cm}$ の被覆化された小腸塊を認め上腸間 膜動脈の背側より小腸が右側後腹膜腔に嵌入したものと考方られた. 胃の拡張はなく通 過障害を思わせる所見は認めなかった，以上より右傍十二指腸へルニアと診断し手術を 施行した。空腸起始部から $150 \mathrm{~cm}$ の小腸が十二指腸上行部の尾側から右側の後腹膜腔に 嵌入しており右傍十二指腸ヘルニアと診断した，嵌入小腸を用手的に整復したところ血 行も改善したため腸切除は行わずへルニア門の縫合閉鎖を行った. 術後嵌入していた小 腸の浮腫のためと考えられる腸管麻㾇を認めたが保存的に軽快し術後48日目に退院し た。傍十二指腸ヘルニアは術前診断が難しいといわれているが自験例では臨床症状やレ ントゲン検査により本疾患に特徽的とされる所見を認め診断が可能であった。

索引用語：傍十二指腸ヘルニア，内ヘルニア

緒 言

傍十二指腸ヘルニアとは十二指腸付近の孔・ヒダに より形成された萑の中に䁍器の嵌入した状態をい う ${ }^{1)}$.ヘルニア豪の部位により左右に分類される.今回 われわれは術前に診断しえた右傍十二指腸へルニアを 経験したので若干の文献的考察を加えて報告する。

\section{症例}

患者：32藏, 男性.

主訴：上腹部痛。

家族歴：特記すべきことなし。

既往歴：28歳時腹痛にて入院歴あり.

現病歴：2003年 2 月 22 日夜より上腹部痛が出琪，改 善しないため 2 月23日午前 8 時当院救急外来受診，同 日入院となった。

入院時現症：身長 $179 \mathrm{~cm}$ •体重 $86 \mathrm{~kg}$. 胸部に心雑音・ 肺雑音認めず．腹部は上腹部に膨隆あるも軟，膨隆部 に一致して自発痛・圧痛認めるも，反跳痛は認めなか

2004年 5 月19日受付 2004 年 9 月27日採用

〈所属施設住所〉

₹586-0017 河内長野市古野町 4-11
った.

入院時血液検查：白血球 $10,600 / \mu 1$ と上昇認める以 外は肝・腎機能や CK・ LDH など含めて正常範囲内で あった（表 1 )。

腹部単純レントゲン所見：小腸ガスと考えられる陰 影が集積しそれにより右側結腸ガスが肝下面へ圧排さ れており後腹膜腫瘤の存在が考えられた（図 1 ).

腹部造影 CT 検査所見：上行結腸の内側, 横行結腸 の背側から尾側に径 $12 \mathrm{~cm}$ の滑らかな境界を持つ被覆 化された小腸塊を認めた。上腸間膜動脈の背側より小 腸が右側後腹膜腔に嵌入したものと考えられた．同部 位の造影は不良であったが罥の拡張はなく通過障害を 思わせる所見は認めなかった（図2）。

以上より右傍十二指腸へルニア・絞扼性イレウスの 術前診断にて同日緊急手術を施行した。

手術所見：上腹部正中切開にて手衡施行. 腹水認め ず. Treitz 靯带よりすぐの空腸間膜に径約 $5 \mathrm{~cm}$ の脆 弱部あり,ここをへルニア門として右上方に小腸約 150 $\mathrm{cm}$ が入り込み嵌頓・絞扼されていた（図 $3 \mathrm{a}$ ). 嵌頓 腸管を整復し検索すると腸管に浮腫は認めたが壊死に は至っておらず腸切除は施行せずへルニア門の閉鎖・ 
表 1 来院時血液生化学所見

\begin{tabular}{|l|l|l|l|l|l|}
\hline WBC & $10,600 / \mathrm{mm}^{3}$ & TP & $6.6 \mathrm{~g} / \mathrm{dl}$ & CPK & $89 \mathrm{U} / 1$ \\
\hline $\mathrm{RBC}$ & $453 \times 10^{4} / \mathrm{mm}^{3}$ & Alb & $4.3 \mathrm{~g} / \mathrm{dl}$ & $\mathrm{LDH}$ & $271 \mathrm{U} / 1$ \\
\hline $\mathrm{Hb}$ & $13.2 \mathrm{~g} / \mathrm{dl}$ & T-Bil & $0.5 \mathrm{mg} / \mathrm{dl}$ & BUN & $10.4 \mathrm{mg} / \mathrm{dl}$ \\
\hline $\mathrm{Ht}$ & $39.6 \%$ & AST & $21 \mathrm{U} / 1$ & Crea & $1.1 \mathrm{mg} / \mathrm{dl}$ \\
\hline $\mathrm{Plt}$ & $20.2 \times 10^{4} / \mathrm{mm}^{3}$ & ALT & $51 \mathrm{U} / 1$ & $\mathrm{Na}$ & $140 \mathrm{mEq} / 1$ \\
\hline $\mathrm{CRP}$ & $<0.3 \mathrm{mg} / \mathrm{dl}$ & Al-P & $205 \mathrm{U} / 1$ & $\mathrm{~K}$ & $3.7 \mathrm{mEq} / 1$ \\
\hline & & Amy & $68 \mathrm{U} / 1$ & $\mathrm{Cl}$ & $98 \mathrm{mEq} / 1$ \\
\hline
\end{tabular}

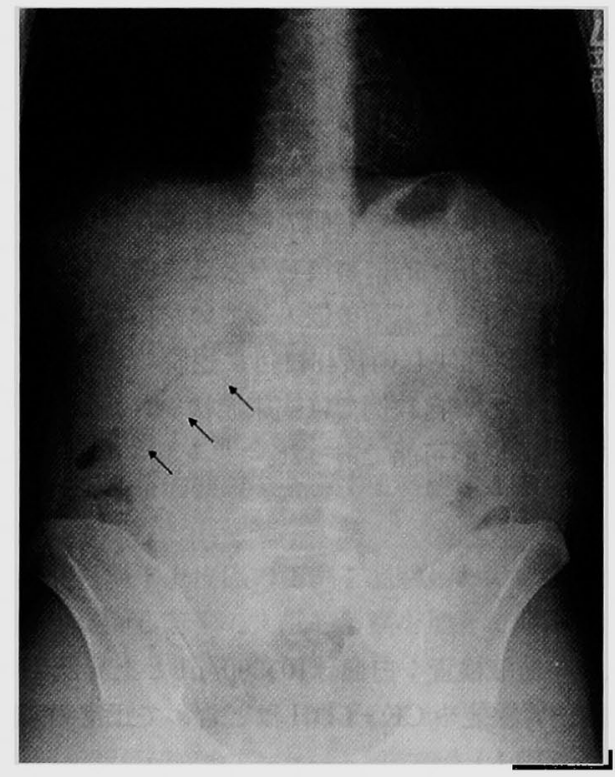

図 1 腹部単純レントゲン所見：右側 結腸ガス が肝下面へ圧排されていた（矢印）.

縫縮のみとした（図 3 b).

術後経過：術後に腸管浮腫によると考えられる麻疸 性イレウスが遷延し, 経口摄取開始は術後33日目とな つたが術後48日目に軽快退院となった。

\section{考 察}

傍十二指腸ヘルニアは，十二指腸付近の孔・ヒダに より形成された寢のなかに臟器の岸入した状態であり 欧米においては内へルニアの原因として最大とされ本 邦においても腸間膜裂孔へルニアに次いで多いとされ $ろ^{122)}$. 右傍十二指腸へルニアはへルニア裛が上行結腸 間膜の後方にあり上腸間膜動静脈の走るヒダがへルニ ア門の前壁を形成しているものをいい，左傍十二指腸 ヘルニアはヘルニア壤が下行結腸間膜の後方にありへ ルニア門の前壁を下腸間膜静脈と左結腸動脈が走るも

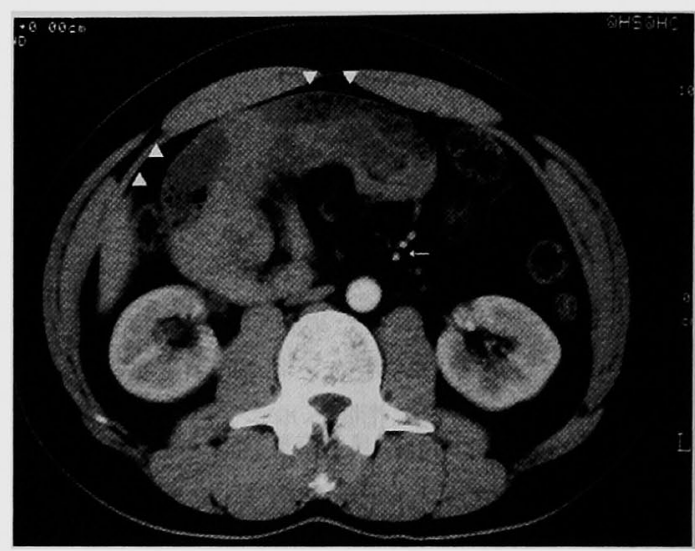

図 2 腹部造影 CT 検查所見：上行結腸の内側, 横行結腸 の背側から尾側に径 $12 \mathrm{~cm}$ の滑らかな境界を持つ被覆 化された小腸塊 $(\nabla)$ を認め上腸間膜動脈 ( より小腸が右側後腹膜腔に嵌入したものと考えられ た.

のをいう.

われわれの検索しえた傍十二指腸ヘルニアの本邦報 告例は1902年新谷以来, 2003 年 8 月大楽の報告まで118 例あり，右が40例・左が74例・不明 4 例でおよそ 1 : 2 と左の発生率が高い. 男女比はおよそ7：3で男に 多い. 症状としては, 腹痛 $(80 \%)$, 哂吐 $(60 \%)$ が多 く, 次いで腹部腫瘤 (10\%), 腹部膨満 $(7 \%)$, 便秘, 下㥒, 吐血などとなっている1).

右傍十二指腸ヘルニアの成因としては胎生期の腸回 転異常が考えられている，小腸が上行結腸間膜背側に 捕らわれた形態となる可能性のある腸回転異常として Bill の分類のIIC とIIID があり，これらはともに臨床 的に右傍十二指腸ヘルニアの形態をとるが Bill は腸 回転異常の分類IICにより発生するものを right paraduodenal hernia，IIID によるものを internal hernia near the ligament of Treitz と区別している゙3. Bill の 

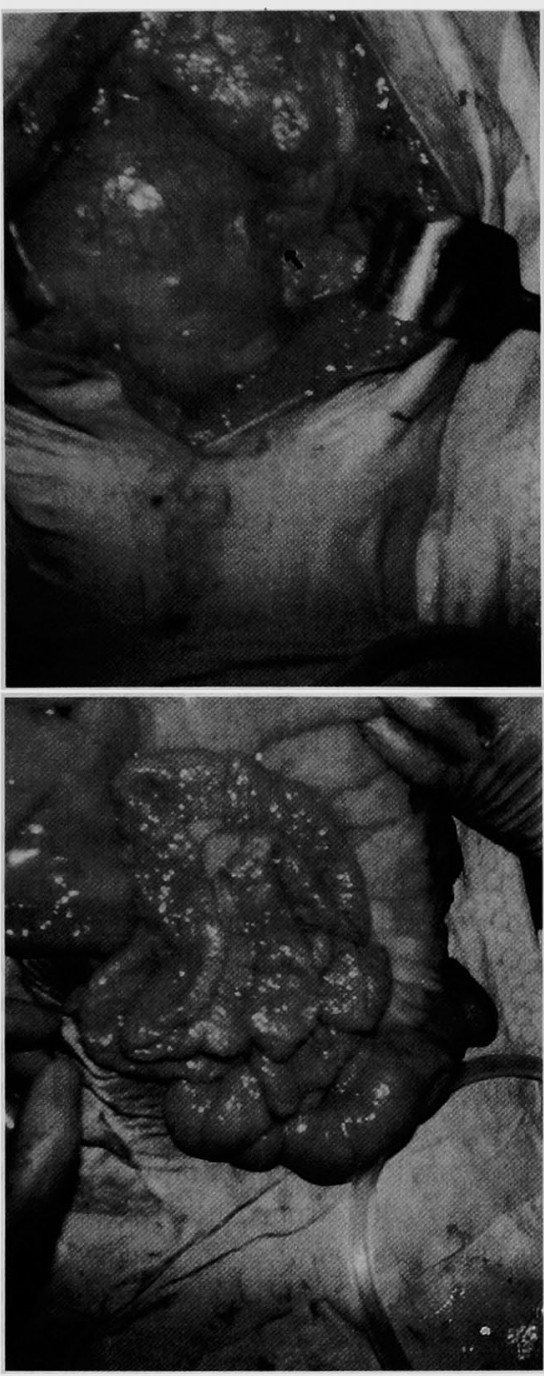

図 3 手術所見：a）Treitz 䨣帯からすぐの 空腸が矢印の部位から上行結腸間膜の背側 に捕われ，あたかも巨大な後腹膜腫瘤を形 成しているようになっていた，b)嵌頓腸管 は浮腫状だったが，血流障害認めず. $\frac{\mathrm{a}}{\mathrm{b}}$

分類IICでは，腸回転の第 2 段階において頭側中腸の 回転が途中で停止し，尾側中腸の回転・固定が正常に 進行することで，頭側中腸（十二指腸・空腸）が正常 に回転した尾側中腸（上行結腸）の間膜背側に捕らわ れることで右傍十二指腸ヘルニアが発生するとされ る. Bill の分類IIID では, 腸回転は正常に行われ腸管の 走行は正常であるが，腸回転の最終段階で腸間膜の後 腹膜への癒合不全により上行結腸間膜背側に形成され
た間隙に腸管が入り込んで右傍十二指腸ヘルニアが発 生するとされる ${ }^{3)-5)}$. 自験例では, 明らかな腸管走行の 異常を認めなかったことより，Bill の分類ではIIID に あたると考えられた。

症状は前記のように小腸の嵌頓による腹痛・嘔吐が 多いが，へルニア門が比較的大きいため，絞扼し腸管 壊死に至る例や，腸管の完全閉塞に至る例は少ないと される112). そのため慢性の消化器症状をきたす例も多 く, 自験例も28歳時の腹痛歴も右傍十二指腸へルニア の症状であった可能性も考えられた。

診断は，傍十二指腸ヘルニアには特異的な検査所見 が少ないとされ，難治性イレウスや絞扼性イレウスの 術前診断にて手術されることが多( ${ }^{24) 66}$. しかし近年, 疾患の認知・画像診断の進歩により術前診断される例 が散見されるようになってきた．特徵的な画像診断所 見として, 腹部単純レントゲン検査ではへルニア襄に 一致して小腸ガスが集積し，これが体位・圧迫などて 変化しないことがあげられる234). 腹部単純 $\mathrm{CT}$ 検査て はへルニア襄に一致する円弧状の境界を持つ小腸係 蹄・線状の腸間膜像が認められ $\left.{ }^{2) 4} \sim 6\right)$ ，造影 $\mathrm{CT}$ 検査に てはそれらに加えて小腸係蹄がヘルニア門を形成する 血管（右傍十二指腸へルニアでは上腸間膜動静脈・左 傍十二指腸へルニアでは下腸間膜静脈・左結腸動脈） の背側を通っていることが認められることがあるとさ れている5). 小腸造影検査においてはへルニア襄部に 一致して小腸係蹄が滑らかな円弧状を呈することがあ

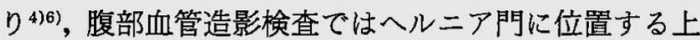
腸間膜動静脈や下腸間膜静脈・左結腸動脈が圧排され ている所見が認められるとされている4). 自験例にお いては腹部単純レントゲン検查, 腹部造影 CT 検査に て特徴的な所見が認められ右傍十二指腸へルニアと診 断しえた。

傍十二指腸へルニアの治療としては, 手術が必要で ヘルニア内容の整復とヘルニア門の閉鎖を行う．一般 的には開腹にて行われた症例がほとんどだが，近年に なり腹腔鏡下に同様の手術を施行する例も報告されて いる7).

\section{結 語}

今回われわれは術前に診断しえた右傍十二指腸へル ニアの 1 例を経験したので若干の文献的考察を加えて 報告した。傍十二指腸へルニアは比較的稀な疾患であ るが, 腹部単純レントゲン・腹部 CT などにて術前診 断可能な疾患であり,手術歴のないイレウス・腹痛にお いては鑑別診断として考慮すべき疾患と考えられた。 


\section{文 献}

1）天野純治：傍十二指腸ヘルニア．冲永功太，ヘル ニアのすべて，第 1 版，へるす出版，東京，1995， $\mathrm{p} 247-263$

2）大谷 聡，井上 仁，三浦純一他：絞扼性イレウ スの診断で手術した右傍十二指腸へルニアの 1

例。日臨外会誌 $63: 383-386,2002$

3) Bill AH : Malrotation of the intestine. Ed. by Ravitch MM, Welch KJ, Benson CD, et al, Pediatric surjery $3^{\text {rd }}$ ed., Year Book Medical Publishers, Chicago, 1979, p912-923

4）田儀知之，植木孝宜，櫻井喜代他：術前 CT $に て$
診断しえた右傍十二指腸ヘルニアの1 例. 京府医 大詸 $112 ： 253-258,2003$

5）寺息政宏, 畑田 剛, 重盛干香他：典型的な CT 像 を呈した右傍十二指腸へルニアの 1 例. 日臨外会 誌 $64: 879-882,2003$

6）飽浦良和, 松本剛昌, 藤原拓造他：CT にて術前診 断した右傍十二指腸へルニアの 1 例. 日臨外会誌 $64: 1122-1124,2003$

7) 中西 史, 三井一浩, 松本 宏他: 左傍十二指腸 ヘルニアの 2 例一開腹手術の 1 例と腹腔鏡下手術 の1例一. 日臨外会誌 $63: 1302-1307,2002$

\title{
A CASE OF RIGHT PARADUODENAL HERNIA DIAGNOSED PREOPERATIVELY
}

\author{
Kohei OTA, Kenichi YANAGAWA and Tetsuya TAKAHATA \\ Department of Surgery, Teramoto Memorial Hospital
}

We present a case of right paraduodenal hernia diagnosed before surgery. A 32-year-old man was admitted to the hospital because of epigastralgia. Laboratory data showed the white blood cell count of $10,600 / \mu 1$. But other blood biochemical data were within the normal ranges including liver, muscle and renal functions. There was distention with tenderness in the upper abdomen, but no peritoneal signs were present. He had experienced the same symptoms at the age of 28 when the symptoms disappeared with hospitalization and treatment for several days. Abdominal plain roentgenogram demonstrated the rightside colon pushed out to the lower wall of liver. Enhanced computed tomography (CT) of the abdomen showed a $12-\mathrm{cm}$ mass of the small intestine at medial side of the ascending colon and dorsal aspect of the transverse colon. It was thought that this mass was formed because the small intestine had penetrated through the dorsal aspect of superior mesenteric artery into the right retroperitneal space. So we diagnosed the case as right paraduodenal hernia and an emergency operation was performed. A $150-\mathrm{cm}$ portion of the proximal jejunum penetrated into the right retroperitneal space through the caudal side of the ascending portion of the duodenum. Because this jejunum had no ischemic change after manual reduction, we only sutured the hernial orifice. He improved despite paresis of intestine and was discharged from the hospital on the 48th day after the operation.

Generally, paraduodenal hernia is difficult to diagnose before operation. In our case, we could diagnose before the operation based on subjective, and objective symptoms, X-ray and CT findings typical of this disease. 